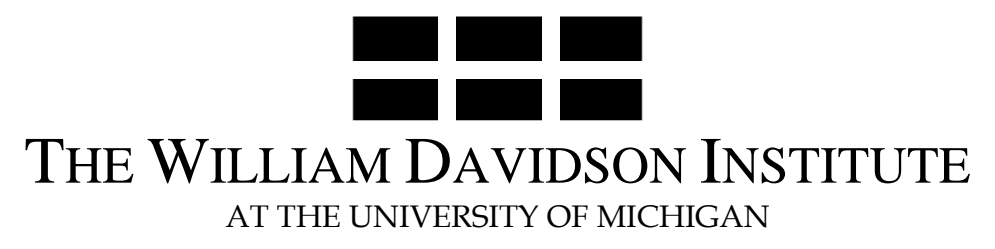

AT THE UNIVERSITY OF MICHIGAN

\title{
A FOREWARNING INDICATOR SYSTEM FOR FINANCIAL CRISES : THE CASE OF SIX CENTRAL AND EASTERN EUROPEAN COUNTRIES
}

By: Irène Andreou, Gilles Dufrénot, Alain Sand-Zantman and Aleksandra Zdzienicka-Durand

William Davidson Institute Working Paper Number 901 May 2007 


\title{
A FOREWARNING INDICATOR SYSTEM FOR FINANCIAL CRISES : THE CASE OF SIX CENTRAL AND EASTERN EUROPEAN COUNTRIES
}

\author{
Irène Andreou, GATE (CNRS,Université Lyon 2) ${ }^{1}$ \\ Gilles Dufrénot, Université Paris 12, GREQAM, Commission Economique de l'UEMOA ${ }^{2}$ \\ Alain Sand-Zantman, OFCE(FNSP) and GATE (CNRS, Université Lyon 2, ENS-LSH) ${ }^{3}$ \\ Aleksandra Zdzienicka-Durand, GATE(CNRS,Université Lyon 2) ${ }^{4}$
}

May 30, 2007

\begin{abstract}
We propose a measure of the probability of crises associated with an aggregate indicator, where the percentage of false alarms and the proportion of missed signals can be combined to give an appreciation of the vulnerability of an economy. In this perspective, the important issue is not only to determine whether a system produces true predictions of a crisis, but also whether there are forewarning signs of a forthcoming crisis prior to its actual occurrence. To this end, we adopt the approach initiated by Kaminsky, Lizondo and Reinhart (1998), analyzing each indicator and calculating each threshold separately. We depart from this approach in that each country is also analyzed separately, permitting the creation of a more “custom-made” early warning system for each one.
\end{abstract}

JEL classification : F31; F47.

Keywords : Currency Crisis, Early Warning System, Composite Indicator, Eastern Europe.

\footnotetext{
${ }^{1}$ GATE-CNRS/ENS LSH, Univ. Lyon 2, 15 Parvis René Descartes BP 7000, 69342 Lyon Cedex 07, Tél.:

+33.4.37.37.60.41. Email : andreou@gate.cnrs.fr

${ }^{2}$ GREQAM-CNRS, Centre de la Vieille Charité, 2 rue de la Charité, 13002, Marseille, Tél.:+33.4.91.14.07.35. Email : lopaduf@aol.com

${ }^{3}$ GATE-CNRS/ENS LSH, Univ. Lyon 2, 15 Parvis René Descartes BP 7000, 69342 Lyon Cedex 07, Tél.: +33.6.85.51.94.83. Email : a.sand@wanadoo.fr

${ }^{4}$ GATE-CNRS/ENS LSH, Univ. Lyon 2, 15 Parvis René Descartes BP 7000, 69342 Lyon Cedex 07, Tél.:

+33.4.37.37.60.41. Email : azdzieni@ens-lsh.fr
} 


\section{Non-technical summary}

In this paper we propose a measure of the probability of crises associated with an aggregate indicator, where the percentage of false alarms and the proportion of missed signals are combined to give an appreciation of the vulnerability of an economy. In this perspective, the important issue is not only to determine whether a system produces true predictions of a crisis, but also whether there are forewarning signs of a forthcoming crisis prior to its actual occurrence. To this end, we adopt a signal extraction approach, following the methodology suggested in previous papers by Kaminsky, Lizondo and Reinhart (1998), Berg and Patillo (1999), Goldstein et al. (2000), and Edison (2003). However, our interpretation contrasts with previous studies in the conception of what a good warning system must be for an emerging economy. In the case of the countries treated in this study, a monitoring system with a high proportion of false crisis signals is not necessarily something bad, as is suggested in the majority of the literature, since it may simply mean that the warning system detects situations of increased vulnerability in a context of deteriorating macroeconomic fundamentals. An intertemporal accumulation of false signals can indicate a high probability that a severe crisis will actually occur in the near future. Therefore, false alarms may simply indicate the deterioration of economic fundamentals and potential forthcoming crises. We propose such an indicator in this paper and show that the predicted probabilities of a currency crisis in Russia and, to a lesser extent, Kazakhstan, have remained high during the early and mid nineties. In contrast, a comparison with other Central and Eastern European countries (such as the Czech Republic, Hungary and Poland) reveals that the probabilities of a crisis were high only a few periods prior to the observed crises and low otherwise.

The forewarning model we propose in this paper differs with respect to several aspects when compared to more conventional forewarning system models based on the signal extraction approach. The main differences are threefold.

Firstly, for several reasons that are explained later, it seems interesting to include among the set of leading indicators a macroeconomic variable that captures the influence of banking crises. Here, we use commercial bank deposits and the ratio of credits to GDP as proxies. The decrease of commercial bank deposits or the rapid expansion of credits are two vectors of banking crises.

Secondly, we use quarterly data, rather than annual or monthly data, as is usually the case, because an annual periodicity is not informative enough. 
Thirdly, to assess the potential risk of a financial crisis, we compute the probability that a crisis will occur provided that the composite indicator exceeds certain threshold values. These threshold values vary with specific countries, as we have tried to adapt the forewarning system to each country's special features and crisis history.

\section{Introduction}

The proliferation of financial crises in the emerging economies during the nineties led the economists to spend great efforts in the building of forewarning indicators that could help prevent the detrimental effects of financial turbulence and assist policymakers in taking appropriate actions. In the literature, several modeling approaches have been suggested as frameworks that can help forecast financial crises. Firstly, the structural models focus on the factors that generate the currency crises : balance of payments crises as described by Krugman (1979) and Flood and Garber (1984); speculative attack models based on the investors' expectations of monetary policy; financial bubble models with moral hazard behaviors (see Krugman, 1998). A second approach consists of models in which the occurrence of financial crises is a consequence of contagion channels : commercial trade, portfolio re-allocations, political channels (see, among others, Eichengreen et al. (1996), Sachs et al. (1996), Glick and Rose (1998), Bussière and Fratzscher (2002), Komulainen and Lukkanila (2002)). Thirdly, several empirical models have also been proposed. They are based on value at risk analysis, logit/probit regressions, Early Warning Systems, and Markovian models (see, among many others, Burkart and Coudert (2002), Abiad (2003), Kumar et al. (2003)).

In this paper we propose a measure of the probability of crises associated with an aggregate indicator, where the percentage of false alarms and the proportion of missed signals are combined to give an appreciation of the vulnerability of an economy. In this perspective, the important issue is not only to determine whether a system produces true predictions of a crisis, but also whether there are forewarning signs of a forthcoming crisis prior to its actual occurrence. To this end, we adopt a signal extraction approach, following the methodology suggested in previous papers by Kaminsky, Lizondo and Reinhart (1998), Berg and Patillo (1999), Goldstein et al. (2000), and Edison (2003). However, our interpretation contrasts with previous studies in the conception of what a good warning system must be for an emerging economy. It is common wisdom that in constructing warning systems, the economists usually 
face a dilemma. On one hand, they attempt to construct a system that yields a high percentage of correctly predicted crises : in this case, the counterpart is a high proportion of false crisis signals. On the other hand, they try to minimize the proportion of false signals, and in this case, they must also accept a low proportion of good crisis predictions. In the case of the countries treated in this study, a monitoring system with a high proportion of false crisis signals is not necessarily something bad, since it may simply mean that the warning system detects situations of increased vulnerability in a context of deteriorating macroeconomic fundamentals. An intertemporal accumulation of false signals can indicate a high probability that a severe crisis will actually occur in the near future. Therefore, false alarms may simply indicate the deterioration of economic fundamentals and potential forthcoming crises. We propose such an indicator in this paper and show that the predicted probabilities of a currency crisis in Russia and, to a lesser extent, Kazakhstan, have remained high during the early and mid nineties. In contrast, a comparison with other Central and Eastern European countries (such as the Czech Republic, Hungary and Poland) reveals that the probabilities of a crisis were high only a few periods prior to the observed crises and low otherwise.

The forewarning model we propose in this paper differs with respect to several aspects when compared to more conventional forewarning system models based on the signal extraction approach. The main differences are threefold.

Firstly, banking system collapses often coincide with the onset of a currency crisis. For example, the biggest difference between Russia and other Eastern European countries was the role of the banking system. In the former, credits have continued to be inefficiently directed towards the big state-owned industrialized conglomerates, bad loans worsened and the absence of supervisory laws induced high inflation and the development of a barter economy. In contrast, in Central and Eastern Europe monetary authorities imposed a control of credits that was part of a tightening monetary policy, signaling the authorities' intention to address appropriately their inflation problem. Such a decision was positively interpreted by the markets and helped assessing the credibility of the monetary policy. In view these observations, it seems interesting to include among the set of leading indicators a macroeconomic variable that captures the influence of banking crises. Here, we use commercial bank deposits and the ratio of credits to GDP as proxies. The decrease of commercial bank deposits or the rapid expansion of credits are two vectors of banking crises.

Secondly, we use quarterly data, rather than annual or monthly data, as is usually the case. Indeed, in the case of Russia, the 1998 crisis was so severe that any preventive action required some precision about the exact dating of the crisis. An annual periodicity is not informative 
enough, because in this case the warning system is unable to predict whether a crisis is going to happen at the beginning or at the end of the year.

Thirdly, to assess the potential risk of a financial crisis, we compute the probability that a crisis will occur provided that the composite indicator exceeds certain threshold values. These threshold values vary with specific countries, as we have tried to adapt the forewarning system to each country's special features and crisis history.

The structure of the paper is as follows. Section 2 presents ten macroeconomic leading indicators and show that their behavior differs around crisis periods. In Section 3, a composite indicator is proposed to estimate the probability of a crisis. Finally, Section 4 concludes.

\section{Single leading indicators for predicting the financial crises}

Financial crises can manifest themselves in several ways : currency crises, banking system collapses, high increase of short-term debt, pressure on the domestic interest rate markets, high inflationary periods yielding financial bubbles, etc. In all cases, one of the cornerstones of financial turbulence in emerging markets is the observation of severe pressure on the domestic currency with high costs on the external balance. We accordingly adopt a criterion for the definition of a crisis that accounts for both pressures occurring in the exchange rate market and diminishing foreign reserves. The market pressure index is defined as follows:

$$
I N D_{t}=\phi_{1} \Delta R E E R_{t}-\phi_{2} \Delta R E S E R V_{t}
$$

where REER is the real exchange rate and RESERV stands for the country's foreign reserves. Market pressure is thus observed when the real exchange rate depreciates and when a country is confronted with reserve losses.

A financial crisis is then defined as follows:

$$
\text { crisis }_{t}= \begin{cases}1, & \text { if } I N D_{t} \geq c \\ 0, & \text { otherwise }\end{cases}
$$

A crisis occurs when pressures in the exchange rate market and foreign reserve losses are very high. By 'high', one means that exchange rate depreciation and foreign reserve losses have reached a threshold value above which their continued decline is not sustainable. The 
identification of a crisis is thus conditioned by three important parameters, $\phi_{1}, \phi_{2}, c$. The latter must be parameterized (or sometimes estimated) by the modeler. It is common wisdom to interpret the weights $\phi_{1}, \phi_{2}$ as measures of the volatility of the changes occurring in the real exchange rate and foreign reserves. We normalize $\phi_{1}$ to 1 and define $\phi_{2}$ as the ratio of the standard deviation of the rate of change of the real exchange rate and the standard deviation of foreign reserve variation : $\phi_{2}=\sigma_{\triangle R E E R} / \sigma_{\triangle R E S E R V}$. The threshold parameter is thus defined as

$$
C=\overline{I N D}+\delta \sigma_{I N D}
$$

where $\overline{I N D}$ is the empirical mean of IND and $\sigma_{I N D}$ is the standard deviation. A crisis occurs when the indicator is $\delta$ standard deviations above its mean. $C$ must be determined optimally, in such a way that the crises identified correspond, at least, to the observed episodes of currency crises in the exchange rate markets. After trying different values, we finally choose $\delta=0.75$. This allows us to capture most of the pressures that the six countries examined in this paper have experienced.

Our study covers the period starting from the first quarter of 1996 and ending at the last quarter of 2003. We use quarterly data for the following countries : Russia, Hungary, Poland, the Slovak Republic, the Czech Republic and Kazakhstan. Our series are taken from the IMF database (IFS statistics). A detailed description of the variables used is given in the appendix.

\section{Evidence of crises provided by the Market Pressure Index}

Figure 1 shows signs of tensions in 1996. Furthermore, the market pressure index crosses its threshold value from the third quarter of 1997 until mid-1998. The index as defined above has the following advantage. Not only does it detect the year 1998 as a crisis period, but it also corroborates the observation that in Russia the 1998 crisis did not appear suddenly, but was the height of an economic crisis that lasted many years (cumulative decline in GDP by more than 40\% between 1989 and 1996, near-hyperinflation) in a context of failure of the reform strategies undertaken during the transition period. Indeed, macroeconomic fundamentals began to seriously deteriorate in 1996 and 1997 and this was the consequence of a combination of factors: deterioration of the terms of trade, fall in oil prices, sharp depreciation of the Ruble, increases in interest rates and internal problems (fiscal and debt 
crises). In addition, the index provides evidence on tensions in mid to late 1999, as well as at the end of the year 2003.

Figures 2-6 depict the case of the other five countries. The Russian crisis and the slowdown of the Western European countries' economies had a negative impact on the Central and Eastern European countries' exports, as well as Foreign Direct Investment, thereby inducing an important slowdown of their activity from 1998 onwards. Moreover, internal issues such as faster growth and higher inflation, as well as fiscal problems, put pressures on these countries' exchange rates. Contagion channels have also been important in explaining financial market turmoil. Figure 6, gives a good illustration of contagion in Kazakhstan. As one sees, the market pressure index has crossed its threshold several times between the first quarter of 1998 and the end of 1999, in the aftermath of the Russian crisis. This can be expected, given the relations and closeness of the two economies. A similar observation could apply to Hungary, Poland and the Slovak and Czech Republics, though the contagion effects have been delayed over time. The graphs corroborate the historical observation that these countries have continued to suffer from contagion effects in the 2000's. It is also important to note that for all of these countries the index gives evidence of the influence of the 1997 Czech crisis (triggered by speculative attacks due to weakening fundamentals and the Asian crisis), which encouraged the CEECs to move towards greater exchange rate flexibility.

\section{Economic indicators}

A central question in the signaling approach is the choice of the crises' potential determinants. For the countries examined in this paper, we consider different categories of explanatory variables:

- a monetary variable : the ratio of M2 to nominal GDP. The upper bound is considered for this variable, because expansionary monetary policy and/or a decline in GDP are associated with the onset of a crisis.

- a capital account variable: the ratio of M2 to foreign exchange reserves. We take into account the upper bound for this variable, because expansionary monetary policy and/or sharp declines in reserves usually precede financial crises. 
- current account variables :

- the real exchange rate : lower bound, for real exchange rate overvaluations (-) are linked to currency crises.

- the value of exports and imports : lower bound for exports and upper bound for imports, because a weak external sector is part of a currency crisis.

- current account balance measured as the ratio of the difference of exports and imports to GDP : lower bound, for the aforementioned reasons.

- banking variables :

- commercial bank deposits : lower bound, for a loss of deposits occurs as a crisis unfolds.

- the ratio of domestic credit to GDP : upper bound, since credit expands prior to a crisis and contracts afterwards.

- real sector indicators : GDP and GDP growth. The lower bound is considered for both these variables, due to the fact that recessions often precede financial crises.

The important issue here is the stability of the financial sector, as is highlighted in third generation currency crisis models. The motivation behind such a choice is rather intuitive. The Russian crisis was part of a huge financial crisis characterized by a weak banking sector and several bankruptcies of financial intermediaries. For the other countries, the reasons for choosing variables that reflect the stability of the financial sector are similar to those evoked when considering the currency crises in the South-East Asian countries: the degree of the severity and spread of a currency crisis occurring in a neighboring country depends upon the fragility of their own financial markets, or in other words, the strength of the banking sector.

The above variables can be considered as warning indicators of a forthcoming financial crisis for several reasons. First, prior to a crisis, domestic credit tends to increase and the rapid growth of credit is transformed into a sharp contraction when the crisis appears. Furthermore, credit expansion is usually observed in the context of an expansionary monetary policy inducing an increase in the ratio of $M 2$ to GDP. Second, a currency crisis generally follows a sharp deterioration of the external balance : loss of competitiveness, current account deficits and foreign reserve losses. Third, an unstable economic situation is a vector of financial crises. Finally, in a context of immature banking sectors, crisis episodes are accompanied by losses of commercial bank deposits. 


\section{Computing noise-to-signal ratios for single indicators}

We consider an on/off signal and a variable, $S_{t}$, that takes the value 1 if a crisis is signaled and 0 otherwise. The prediction of a crisis or a calm period depends upon the behavior of a macroeconomic variable. A crisis signal is detected when this variable deviates from its usual values beyond a certain threshold level:

$$
\text { signal: } \quad S_{t}= \begin{cases}1, & \text { if }\left|X_{t}\right| \geq \bar{X} \\ 0, & \left|X_{t}\right|<\bar{X}\end{cases}
$$

where $X$ is a macroeconomic variable. Note that we need a signaling horizon, that is the time horizon at which a variable is expected to predict a crisis. In this paper, we consider a signaling period of four quarters. To define the optimal value of the threshold $\bar{X}$, we proceed as follows. Consider the following events:

A: the variable predicts a crisis and the crisis occurs within four quarters (good 'on' signal) B: the variable predicts a crisis, but no crisis occurs during the signaling period (false crisis signal)

C: the variable does not predict a crisis, but a crisis occurs (missed crisis signal or false calm signal)

D: The variable does not predict a crisis and no crisis occurs (good 'off' signal)

These four situations are summarized in the following matrix:

\begin{tabular}{|c|c|c|}
\hline \multicolumn{3}{|c|}{ Table 1 : Indicator Performance } \\
\hline & Crisis within four quarters & No crisis within four quarters \\
\hline Signal issued by indicator & A & B \\
\hline No signal issued by indicator & C & D \\
\hline
\end{tabular}

We define the following test:

$$
\left\{\begin{array}{c}
H_{0}: \text { a crisis occurs } \\
\quad \text { against } \\
H_{1}: \text { a crisis does not occur }
\end{array}\right.
$$


or

$$
\left\{\begin{array}{r}
H_{0}: A \cup C \\
\text { against } \\
H_{1}: B \cup D
\end{array}\right.
$$

A type I error of this test is the probability of rejecting $H_{0}$ when it is true and is defined as $P(C / A \cup C)$. A type II error is the probability of accepting $H_{0}$ when $H_{1}$ is true, that is $P(B / B \cup D)$. The noise-to-signal ratio is defined as the ratio of type II errors over 1 minus type I errors :

$$
\alpha=\frac{P(B / B \cup D)}{1-P(C / A \cup C)}=\frac{P(B / B \cup D)}{P(A / A \cup C)}
$$

The noise-to-signal ratio is thus the ratio of false signals to good signals. A macroeconomic variable is considered as a good warning indicator of a currency crisis if this ratio has values near 0 . Accordingly, the threshold $\bar{X}$, to be selected, must minimize the above ratio. To do this, we use the quantiles of the variable $X$ and retain those yielding the lowest value of $\alpha$. We also compute the probability of correctly predicting a crisis :

$$
\beta=\frac{P(A)}{P(A \cup B)}
$$

\section{Performance of economic indicators}

Tables 2-7 display the results for the six countries. Column 1 reports the quantiles corresponding to the minimum noise-to-signal ratio for each indicator. In all cases, the quantiles chosen vary with the macroeconomic indicator under consideration. Generally, we could say that for the countries where the quantiles chosen are, in majority, situated below Q5, the proportion of observations corresponding to crises in higher in comparison with those of the periods considered as tranquil. As a consequence, the risk of emitting false signals of future calm periods (or missed signals) is low. When the majority of quantiles chosen is situated above Q5, the conclusion is the opposite. As a high value for the threshold increases 
the proportion of tranquil periods, the risk of emitting false signals of calm periods is increased.

Column 3 reports the noise-to-signal ratio. The indicators have a good explanatory power if the ratio is lower than 1 . As seen, this is the case for a majority of variables for the six countries.

For Russia, a bad score is reported by the indicator M2/GDP. This is understandable in a context where the degree of intermediation of the economy is very weak. A better score is obtained by the real exchange rate, a conclusion that is in line with the usual findings in the empirical literature, and the best scores are obtained by GDP, the ratio of the current account to GDP and commercial bank deposits. Though the ratio is lower than 1 for a majority of variables, it seems quite difficult to find indicators with a high degree of reliability in the prediction of financial crises in Russia. This is seen in the fourth column of Table 2, where the ratio of crises accurately predicted has a rather limited explanatory power for many variables, even some of those displaying the lowest noise-to-signal ratios. These findings for Russia corroborate what was observed historically, namely, the difficulty for multilateral international organizations to anticipate the 1998 crisis and to construct reliable forewarning systems.

For Hungary, the best indicators in terms of noise-to-signal ratios are imports and M2/Reserves, which also give satisfactory scores in terms of percentage of correctly called crises and probability of crisis when a warning signal is emitted by these indicators. As far as Poland is concerned, the best indicator is indisputably the ratio of the current account to GDP. This is not the case for the Slovak Republic, where the best results are given by the real effective exchange rate and the commercial bank deposits variable, a situation mirrored closely by Kazakhstan, as well as the Czech Republic, where the real effective exchange rate also scores high.

In general, good scores are often obtained by the real effective exchange rate (REER), as in most of the recent literature, and the commercial bank deposits variables (supporting the view that banking, financial and currency crises are closely related). However, unsatisfactory scores are usually obtained by M2-based variables and the growth rate variable. According to historical observations, one can explain these results as follows. On one hand, Hungary, Poland, Slovakia and the Czech Republic have experienced successful transitions through a liberalization of the foreign trade sector and a restructuring of their economy, which has increased their credibility vis à vis the financial markets. These reforms have contributed to attenuate the severity of the speculative attacks on the local currencies. On the other hand, the 
economic growth that resulted from successful transition policies has been predominantly concentrated in services and the impact on the manufacturing sector has been limited. The bad performance of the GDP growth might be due to the fact that an aggregate index of growth has an imperfect explanatory power. Further, the fact that ratios and growth rates have a lower explanatory power than variables expressed in nominal terms, may partly reflect the fact that the inflation rate has a high signaling role for the financial markets. It is the successful policy of inflation moderation that renders the exports more competitive in the foreign trade markets. It is the liberalization of prices that reduces the difference between the domestic and world prices, thereby limiting the negative pass-trough effects on the imports and the activity. These effects contribute to increase the level of foreign reserves, thereby preventing the risk of a financial crisis.

\section{Composite indicator and the probability of a crisis}

The next step is to combine the different macroeconomic indicators. This avoids placing too strong an emphasis on one variable in particular. Single indicators contain only partial information on forthcoming crises. In order to evaluate the forecasting performance of our indicators in tracking currency crises, we compute the following noise-to-signal ratio weighted indicator:

$$
I_{t}=\sum_{j}\left(1 / \alpha_{j}\right) * S_{t}^{j}
$$

where the index $j$ denotes a macroeconomic indicator, $\alpha_{j}$ is the noise-to-signal ratio obtained for the indicator $j$ and $s$ is the signal variable defined above. The signal variable is weighted by the inverse of the noise to signal ratio, thereby giving more weight to indicators that reported low scores. The performance of this composite indicator can be tested using several criteria. Here, it is used to compute the conditional probability of a currency crisis :

$$
\begin{aligned}
& P\left(C_{t, t+h} / I_{L}<I_{t}<I_{U}\right)= \\
& \frac{\sum \text { quarters with } I_{L}<I_{t}<I_{U} \text {, given that a crisis occurs within } h \text { quarters }}{\sum \text { quarters with } I_{L}<I_{t}<I_{U}}
\end{aligned}
$$


We evaluate the probability that a crisis will occur within $h$ quarters ( $h=4$ in this case), provided that the composite indicator is included within certain threshold values, $I_{L}$ (lower bound) and $I_{U}$ (upper bound). These bounds are determined exogenously and do not vary with time, but they do vary from country to country (according to specific characteristics and the values of the composite indicator), permitting the establishment of more custom-made intervals for each country considered.

Once the upper and lower bounds have been determined, we then proceed to the calculation of the empirical conditional probability that a crisis will occur within four quarters given that the composite indicator is included within a certain interval. The results for these calculations are given in Tables 8 to 13. For example, the conditional probability that a crisis will occur in Russia within $t+3$, quarters given that the composite indicator at $t=1$ takes the value 12 , is 0.6. Overall, these calculations give reasonable and coherent results, in that in most cases the conditional probability of a crisis tends to increase monotonically with the value of the composite indicator, and tends towards 1 (certainty of a crisis) at very high indicator values.

Table 14 displays simultaneously the value of the composite indicator for each period, the conditional probability associated with it, and the incidence of crises, for each country studied. Analyzing the behavior of the composite indicator, we clearly distinguish two situations. In the cases of Hungary (columns 4-6) and Poland (columns 7-9), the highest probabilities of crises are obtained when a crisis is imminent, or when a crisis actually occurs. During the periods of non-crisis, the probability values remain relatively small. For the remaining countries, the conclusion is slightly different. The probabilities are high for a longer period before a crisis (especially at the beginning of the nineties), and in the case of the Czech Republic are relatively high for the majority of the period under study. The warning system thus seems to perform rather well for these countries.

\section{Conclusion}

The warning system presented here could be refined by adopting approaches recently suggested in the empirical literature, for instance regime switching Markovian early warning systems (Arias and Erlandsson (2004)). However, defining an agenda whereby more sophisticated models have to be constructed, seems a difficult task in the case of Russia, given the degree of the spread and detrimental economic repercussions of the 1998 crisis. The 
current state of the macroeconomic fundamentals does not exclude a repetition of such a crisis in the future. A more promising approach would be to complete our early warning system with other standard approaches : value at risk analysis, logit/probit analysis, and event analysis. The greatest difficulty is to obtain reliable data over the period of the nineties, which reduces the number of potential indicators that can be used in the analysis.

A general conclusion that emerges from this paper is the following. We have proposed a measure of the probability of crises associated to an aggregate indicator, where the percentage of false alarms and the proportion of missed signals can be combined to give an appreciation of the vulnerability of an economy. In this perspective, the important problem is not only whether a system produces true predictions of a crisis, but also whether there are forewarning signs of a forthcoming crisis prior its actual occurrence. For purposes of prevention, policymakers need to have advance warnings in the medium/long-term rather than just a few periods prior to a crisis. Our system seems to perform rather well in this respect for most of the countries studied, but a future venue of research might seek to integrate an indicator for contagion effects to further improve the performance of an early warning system. 


\section{APPENDIX}

\section{Table 1 : Data Description}

\begin{tabular}{ll}
\hline \multicolumn{1}{c}{ Indicators } & \multicolumn{1}{c}{ Definition and units } \\
\hline 1. Real exchange rates & Real effective exchange rate (CPI-based) - Index number \\
2. M2 & Quasi-money - National currency - Millions, Billions \\
3. Credit & Domestic credit - National currency - Millions, Billions \\
4. Reserves & Total reserves minus gold - US Dollars - Millions, Billions \\
5. GDP & GDP, production - National currency - Millions, Billions \\
6. Commercial bank & Demand deposits + Government deposits - National currency \\
deposits & - Millions, Billions \\
7. Imports & Imports of goods and services - Millions, Billions \\
8. Exports & Exports of goods and services - Millions, Billions. \\
\hline
\end{tabular}

Source : International Financial Statistics (IFS), International Monetary Fund 
Table 2 : Performance of Single Indicators : Russia

\begin{tabular}{|l|c|c|c|c|c|}
\hline \multicolumn{1}{|c|}{$\begin{array}{c}\text { Advance } \\
\text { Indicator }\end{array}$} & $\begin{array}{c}\text { Threshold } \\
\text { Quantile }\end{array}$ & $\begin{array}{c}\text { Number } \\
\text { of Crises } \\
\text { Called }\end{array}$ & $\begin{array}{c}\text { Noise to } \\
\text { Signal } \\
\text { Ratio }\end{array}$ & $\begin{array}{c}\text { \% of Crises } \\
\text { Correctly } \\
\text { Called }^{5}\end{array}$ & P(Crisis/Signal) \\
\hline REER & Q1 & 4 & 0,31 & $21,43 \%$ & 0,75 \\
\hline M2 / GDP & Q8 & 7 & 0,93 & $14,29 \%$ & 0,50 \\
\hline M2 / Reserves & Q9 & 4 & 0,31 & $21,43 \%$ & 0,75 \\
\hline Domestic Credit / GDP & Q9 & 7 & 0,31 & $21,43 \%$ & 0,75 \\
\hline Exports of Goods and Services & Q3 & 10 & 0,23 & $57,14 \%$ & 0,80 \\
\hline Imports of Goods and Services & Q8 & 7 & 0,93 & $14,29 \%$ & 0,50 \\
\hline GDP & Q2 & 7 & 0,16 & $42,86 \%$ & 0,86 \\
\hline Growth & Q4 & 13 & 0,67 & $50,00 \%$ & 0,58 \\
\hline (EXP-IMP)*100 / GDP & Q2 & 7 & 0,16 & $42,86 \%$ & 0,86 \\
\hline Commercial Bank Deposits & Q4 & 13 & 0,28 & $71,43 \%$ & 0,77 \\
\hline
\end{tabular}

Source : Authors’ Calculations

Table 3 : Performance of Single Indicators : Hungary

\begin{tabular}{|l|c|c|c|c|c|}
\hline \multicolumn{1}{|c|}{$\begin{array}{c}\text { Advance } \\
\text { Indicator }\end{array}$} & $\begin{array}{c}\text { Threshold } \\
\text { Quantile }\end{array}$ & $\begin{array}{c}\text { Number } \\
\text { of Crises } \\
\text { Called }\end{array}$ & $\begin{array}{c}\text { Noise to } \\
\text { Signal } \\
\text { Ratio }\end{array}$ & $\begin{array}{c}\text { \% of Crises } \\
\text { Correctly } \\
\text { Called }\end{array}$ & P(Crisis/Signal) \\
\hline REER & Q3 & 10 & 0,48 & $42,11 \%$ & 0,80 \\
\hline M2 / GDP & Q8 & 7 & 0,63 & $15,79 \%$ & 0,75 \\
\hline M2 / Reserves & Q6 & 13 & 0,21 & $47,37 \%$ & 0,90 \\
\hline Domestic Credit / GDP & Q8 & 7 & 0,32 & $31,58 \%$ & 0,86 \\
\hline Exports of Goods and Services & Q2 & 7 & 0,76 & $26,32 \%$ & 0,71 \\
\hline Imports of Goods and Services & Q6 & 13 & 0,21 & $47,37 \%$ & 0,90 \\
\hline GDP & Q2 & 7 & 0,76 & $26,32 \%$ & 0,71 \\
\hline Growth & Q8 & 27 & 0,71 & $84,21 \%$ & 0,73 \\
\hline (EXP-IMP)*100 / GDP & Q1 & 4 & 0,63 & $15,79 \%$ & 0,75 \\
\hline Commercial Bank Deposits & Q2 & 7 & 0,76 & $26,32 \%$ & 0,71 \\
\hline
\end{tabular}

Source : Authors’ Calculations

\footnotetext{
${ }^{5}$ This percentage can be computed as $(\mathrm{A} / \mathrm{A}+\mathrm{C})$.

${ }^{6}$ This probability corresponds to $\beta$, and is calculated as $(A / A+B)$.
} 
Table 4 : Performance of Single Indicators : Poland

\begin{tabular}{|l|c|c|c|c|c|}
\hline \multicolumn{1}{|c|}{$\begin{array}{c}\text { Advance } \\
\text { Indicator }\end{array}$} & $\begin{array}{c}\text { Threshold } \\
\text { Quantile }\end{array}$ & $\begin{array}{c}\text { Number } \\
\text { of Crises } \\
\text { Called }\end{array}$ & $\begin{array}{c}\text { Noise to } \\
\text { Signal } \\
\text { Ratio }\end{array}$ & $\begin{array}{c}\text { \% of Crises } \\
\text { Correctly } \\
\text { Called }\end{array}$ & P(Crisis/Signal) \\
\hline REER & Q1 & 4 & 0,55 & $16,67 \%$ & 0,75 \\
\hline M2 / GDP & Q5 & 16 & 0,73 & $50,00 \%$ & 0,69 \\
\hline M2 / Reserves & Q4 & 19 & 0,74 & $61,11 \%$ & 0,69 \\
\hline Domestic Credit / GDP & Q5 & 16 & 0,73 & $50,00 \%$ & 0,69 \\
\hline Exports of Goods and Services & Q7 & 22 & 0,76 & $83,33 \%$ & 0,68 \\
\hline Imports of Goods and Services & Q3 & 22 & 0,58 & $77,78 \%$ & 0,74 \\
\hline GDP & Q1 & 4 & 0,55 & $16,67 \%$ & 0,75 \\
\hline Growth & Q1 & 4 & 0,55 & $16,67 \%$ & 0,75 \\
\hline (EXP-IMP)*100 / GDP & Q3 & 10 & 0,18 & $50,00 \%$ & 0,90 \\
\hline Commercial Bank Deposits & Q1 & 4 & 0,55 & $16,67 \%$ & 0,75 \\
\hline
\end{tabular}

Source : Authors’ Calculations

Table 5 : Performance of Single Indicators : Slovak Republic

\begin{tabular}{|l|c|c|c|c|c|}
\hline \multicolumn{1}{|c|}{$\begin{array}{c}\text { Advance } \\
\text { Indicator }\end{array}$} & $\begin{array}{c}\text { Threshold } \\
\text { Quantile }\end{array}$ & $\begin{array}{c}\text { Number } \\
\text { of Crises } \\
\text { Called }\end{array}$ & $\begin{array}{c}\text { Noise to } \\
\text { Signal } \\
\text { Ratio }\end{array}$ & $\begin{array}{c}\text { \% of Crises } \\
\text { Correctly } \\
\text { Called }\end{array}$ & P(Crisis/Signal) \\
\hline REER & Q2 & 7 & 0,16 & $42,86 \%$ & 0,86 \\
\hline M2 / GDP & Q7 & 10 & 0,93 & $35,71 \%$ & 0,50 \\
\hline M2 / Reserves & Q9 & 4 & 0,31 & $21,43 \%$ & 0,75 \\
\hline Domestic Credit / GDP & Q5 & 16 & 0,73 & $64,29 \%$ & 0,56 \\
\hline Exports of Goods and Services & Q5 & 16 & 0,42 & $78,57 \%$ & 0,69 \\
\hline Imports of Goods and Services & Q2 & 25 & 0,93 & $78,57 \%$ & 0,50 \\
\hline GDP & Q5 & 16 & 0,42 & $78,57 \%$ & 0,69 \\
\hline Growth & Q1 & 4 & 0,31 & $21,43 \%$ & 0,75 \\
\hline (EXP-IMP)*100 / GDP & Q3 & 10 & 0,62 & $42,86 \%$ & 0,60 \\
\hline Commercial Bank Deposits & Q3 & 10 & 0,23 & $57,14 \%$ & 0,80 \\
\hline
\end{tabular}

Source : Authors’ Calculations 
Table 6 : Performance of Single Indicators : Czech Republic

\begin{tabular}{|l|c|c|c|c|c|}
\hline \multicolumn{1}{|c|}{$\begin{array}{c}\text { Advance } \\
\text { Indicator }\end{array}$} & $\begin{array}{c}\text { Threshold } \\
\text { Quantile }\end{array}$ & $\begin{array}{c}\text { Number } \\
\text { of Crises } \\
\text { Called }\end{array}$ & $\begin{array}{c}\text { Noise to } \\
\text { Signal } \\
\text { Ratio }\end{array}$ & $\begin{array}{c}\text { \% of Crises } \\
\text { Correctly } \\
\text { Called }\end{array}$ & P(Crisis/Signal) \\
\hline REER & Q3 & 10 & 0,29 & $42,86 \%$ & 0,90 \\
\hline M2 / GDP & Q2 & 25 & 0,77 & $80,95 \%$ & 0,77 \\
\hline M2 / Reserves & Q7 & 10 & 0,29 & $42,86 \%$ & 0,90 \\
\hline Domestic Credit / GDP & Q8 & 7 & 0,45 & $28,57 \%$ & 0,86 \\
\hline Exports of Goods and Services & Q2 & 7 & 0,45 & $28,57 \%$ & 0,86 \\
\hline Imports of Goods and Services & Q8 & 7 & 0,88 & $14,29 \%$ & 0,95 \\
\hline GDP & Q2 & 7 & 0,44 & $28,57 \%$ & 0,86 \\
\hline Growth & Q3 & 10 & 0,66 & $38,10 \%$ & 0,80 \\
\hline (EXP-IMP)*100 / GDP & Q7 & 23 & 0,46 & $80,95 \%$ & 0,85 \\
\hline Commercial Bank Deposits & Q8 & 25 & 0,50 & $100,00 \%$ & 0,84 \\
\hline
\end{tabular}

Source : Authors’ Calculations

Table 7 : Performance of Single Indicators : Kazakhstan

\begin{tabular}{|l|c|c|c|c|c|}
\hline \multicolumn{1}{|c|}{$\begin{array}{c}\text { Advance } \\
\text { Indicator }\end{array}$} & $\begin{array}{c}\text { Threshold } \\
\text { Quantile }\end{array}$ & $\begin{array}{c}\text { Number } \\
\text { of Crises } \\
\text { Called }\end{array}$ & $\begin{array}{c}\text { Noise to } \\
\text { Signal } \\
\text { Ratio }\end{array}$ & $\begin{array}{c}\text { \% of Crises } \\
\text { Correctly } \\
\text { Called }\end{array}$ & P(Crisis/Signal) \\
\hline REER & Q2 & 7 & 0,14 & $46,15 \%$ & 0,86 \\
\hline M2 / GDP & Q1 & 28 & 1,03 & $84,62 \%$ & 0,44 \\
\hline M2 / Reserves & Q1 & 28 & 1,03 & $84,62 \%$ & 0,44 \\
\hline Domestic Credit / GDP & Q2 & 25 & 0,98 & $76,92 \%$ & 0,45 \\
\hline Exports of Goods and Services & Q4 & 13 & 0,51 & $61,54 \%$ & 0,62 \\
\hline Imports of Goods and Services & Q2 & 25 & 0,81 & $84,62 \%$ & 0,50 \\
\hline GDP & Q4 & 13 & 0,51 & $61,54 \%$ & 0,62 \\
\hline Growth & Q8 & 25 & 0,74 & $92,31 \%$ & 0,52 \\
\hline (EXP-IMP)*100 / GDP & Q2 & 7 & 0,14 & $46,15 \%$ & 0,86 \\
\hline Commercial Bank Deposits & Q2 & 7 & 0,14 & $46,15 \%$ & 0,86 \\
\hline
\end{tabular}

Source : Authors’ Calculations 
Table 8 : Conditional Probabilities of Financial Crises : Russia

$\begin{array}{cc}\text { Value Of Composite Index } & \text { Probability of Crisis } \\ 0-2 & 0,0000 \\ 2-5 & 0,4286 \\ 5-10 & 0,5000 \\ 10-15 & 0,6000 \\ \text { Over } 15 & 1,0000\end{array}$

Source : Authors' Calculations

Table 9 : Conditional Probabilities of Financial Crises : Hungary

$\begin{array}{cc}\text { Value Of Composite Index } & \text { Probability of Crisis } \\ 0-2 & 0,1667 \\ 2-5 & 0,6000 \\ 5-10 & 0,6667 \\ 10-12 & 1,0000 \\ \text { Over } 12 & 0,8333\end{array}$

Source : Authors' Calculations

Table 10 : Conditional Probabilities of Financial Crises : Poland

$\begin{array}{cc}\text { Value Of Composite Index } & \text { Probability of Crisis } \\ 0-2 & 0,0000 \\ 2-6 & 0,6250 \\ 6-10 & 0,6364 \\ 10-13 & 1,0000 \\ \text { Over } 13 & 1,0000\end{array}$

Source : Authors' Calculations 
Table 11 : Conditional Probabilities of Financial Crises : Slovak Republic

Value Of Composite Index

$0-3$

$3-5$

$5-10$

$10-13$

Over 13

Source : Authors' Calculations
Probability of Crisis

0,0000

0,2000

0,3333

0,7500

0,8333

Table 12 : Conditional Probabilities of Financial Crises : Czech Republic

Value Of Composite Index
$0-2$
$2-5$
$5-10$
$10-15$
Over 15

Source : Authors' Calculations
Probability of Crisis

0,0000

0,1667

0,9000

0,8571

1,0000

\section{Table 13 : Conditional Probabilities of Financial Crises : Kazakhstan}

$\begin{array}{cc}\text { Value Of Composite Index } & \text { Probability of Crisis } \\ 0-5 & 0,0000 \\ 5-10 & 0,3571 \\ 10-20 & 0,6667 \\ 20-30 & 0,8000 \\ \text { Over } 30 & 1,0000\end{array}$

Source : Authors' Calculations 
Table 14 : Summary Table : Composite Indicator, Conditional Probability and Incidence of Crises

\begin{tabular}{|c|c|c|c|c|c|c|c|c|c|c|c|c|c|c|c|c|c|c|}
\hline & \multicolumn{3}{|c|}{ RUSSIA } & \multicolumn{3}{|c|}{ HUNGARY } & \multicolumn{3}{|c|}{ POLAND } & \multicolumn{3}{|c|}{ SLOVAK REPUBLIC } & \multicolumn{3}{|c|}{ CZECH REPUBLIC } & \multicolumn{3}{|c|}{ KAZAKHSTAN } \\
\hline & \begin{tabular}{|c} 
Composite \\
Indicator
\end{tabular} & $\begin{array}{l}\text { Conditional } \\
\text { Probability }\end{array}$ & $\begin{array}{r}\text { Incidence } \\
\text { of Crises }\end{array}$ & \begin{tabular}{|c} 
Composite \\
Indicator
\end{tabular} & $\begin{array}{l}\text { Conditional } \\
\text { Probability }\end{array}$ & $\begin{array}{c}\text { Incidence } \\
\text { of Crises }\end{array}$ & \begin{tabular}{|c|} 
Composite \\
Indicator
\end{tabular} & \begin{tabular}{|c|} 
Conditional \\
Probability
\end{tabular} & $\begin{array}{r}\text { Incidence } \\
\text { of Crises }\end{array}$ & \begin{tabular}{|c} 
Composite \\
Indicator
\end{tabular} & $\begin{array}{l}\text { Conditional } \\
\text { Probability }\end{array}$ & \begin{tabular}{|c} 
Incidence \\
of Crises
\end{tabular} & \begin{tabular}{|c} 
Composite \\
Indicator
\end{tabular} & \begin{tabular}{|c} 
Conditional \\
Probability
\end{tabular} & $\begin{array}{c}\text { Incidence } \\
\text { of Crises }\end{array}$ & \begin{tabular}{|c} 
Composite \\
Indicator
\end{tabular} & $\begin{array}{c}\text { Conditional } \\
\text { Probability }\end{array}$ & $\begin{array}{r}\text { Incidence } \\
\text { of Crises }\end{array}$ \\
\hline 1996Q1 & 22,2143 & 1,0000 & 0 & 10,6140 & 1,0000 & 1 & 6,8095 & 0,6364 & 0 & 10,6071 & 0,7500 & 0 & 15,7397 & 1,0000 & 1 & 7,2738 & 0,3571 & 0 \\
\hline 1996Q2 & 20,7143 & 1,0000 & 1 & 10,6140 & 1,0000 & 1 & 6,8095 & 0,6364 & 0 & 11,1429 & 0,7500 & 0 & 15,7397 & 1,0000 & 1 & 6,2482 & 0,3571 & 0 \\
\hline 1996Q3 & 14,2857 & 0,6000 & 0 & 12,1930 & 0,8333 & 0 & 6,8095 & 0,6364 & 0 & 11,1429 & 0,7500 & 0 & 15,7397 & 1,0000 & 1 & 4,9055 & 0,0000 & 0 \\
\hline 1996Q4 & 15,7857 & 1,0000 & 0 & 9,2105 & 0,6667 & 0 & 3,1429 & 0,6250 & 0 & 12,7500 & 0,7500 & 0 & 15,7397 & 1,0000 & 0 & 7,2152 & 0,3571 & 0 \\
\hline 1997Q1 & 15,7857 & 1,0000 & 0 & 10,6140 & 1,0000 & 1 & 4,9762 & 0,6250 & 1 & 18,4133 & 0,8333 & 0 & 17,2635 & 1,0000 & 1 & 21,9844 & 0,8000 & 0 \\
\hline 1997Q2 & 20,7143 & 1,0000 & 0 & 6,0526 & 0,6667 & 0 & 1,3095 & 0,0000 & 0 & 8,7704 & 0,3333 & 1 & 14,4444 & 0,8571 & 0 & 29,6328 & 0,8000 & 0 \\
\hline 1997Q3 & 14,2857 & 0,6000 & 1 & 7,4561 & 0,6667 & 0 & 1,3095 & 0,0000 & 0 & 6,0918 & 0,3333 & 0 & 9,8730 & 0,9000 & 0 & 17,9692 & 0,6667 & 0 \\
\hline 1997Q4 & 15,7857 & 1,0000 & 1 & 0,0000 & 0,1667 & 0 & 6,8095 & 0,6364 & 0 & 6,0918 & 0,3333 & 0 & 14,5968 & 0,8571 & 0 & 23,2152 & 0,8000 & 0 \\
\hline 1998Q1 & 25,4286 & 1,0000 & 1 & 4,5614 & 0,6000 & 0 & 1,3095 & 0,0000 & 0 & 13,0561 & 0,8333 & 0 & 10,5333 & 0,8571 & 0 & 15,6254 & 0,6667 & 1 \\
\hline 1998Q2 & 14,2857 & 0,6000 & 0 & 1,4035 & 0,1667 & 0 & 1,3095 & 0,0000 & 0 & 13,0561 & 0,8333 & 0 & 5,4286 & 0,9000 & 1 & 31,6254 & 1,0000 & 0 \\
\hline 1998Q3 & 6,7857 & 0,5000 & 0 & 3,5088 & 0,6000 & 0 & 3,0206 & 0,6250 & 0 & 11,4490 & 0,7500 & 0 & 2,0000 & 0,1667 & 1 & 30,6584 & 1,0000 & 1 \\
\hline 1998Q4 & 10,0000 & 0,6000 & 0 & 3,5088 & 0,6000 & 0 & 8,5206 & 0,6364 & 0 & 22,6990 & 0,8333 & 0 & 6,9778 & 0,9000 & 1 & 24,2408 & 0,8000 & 0 \\
\hline 1999Q1 & 13,2143 & 0,6000 & 0 & 8,2456 & 0,6667 & 1 & 13,1040 & 1,0000 & 0 & 22,1633 & $\mathbf{0 , 8 3 3 3}$ & 1 & 4,8190 & 0,1667 & 0 & 23,0101 & $\mathbf{0 , 8 0 0 0}$ & 1 \\
\hline 1999Q2 & 6,4286 & 0,5000 & 0 & 0,0000 & 0,1667 & 0 & 12,6151 & 1,0000 & 1 & 21,0918 & 0,8333 & 0 & 5,4286 & 0,9000 & 0 & 7,5024 & 0,3571 & 1 \\
\hline 1999Q3 & 3,2143 & 0,4286 & 1 & 1,4035 & 0,1667 & 0 & 11,2401 & 1,0000 & 0 & 10,9286 & 0,7500 & 1 & 2,0000 & 0,1667 & 0 & 3,2234 & 0,0000 & 0 \\
\hline 1999Q4 & 4,7143 & 0,4286 & 0 & 0,0000 & 0,1667 & 0 & 9,8651 & 0,6364 & 0 & 11,4490 & 0,7500 & 0 & 5,6825 & 0,9000 & 0 & 5,5331 & 0,3571 & 0 \\
\hline 2000Q1 & 3,2143 & 0,4286 & 0 & 2,9825 & 0,6000 & 0 & 14,4484 & 1,0000 & 1 & 10,1633 & 0,7500 & 1 & 6,9778 & 0,9000 & 0 & 5,5331 & 0,3571 & 0 \\
\hline 2000Q2 & 0,0000 & 0,0000 & 0 & 1,4035 & 0,1667 & 0 & 12,6151 & 1,0000 & 0 & 5,3571 & 0,3333 & 0 & 8,8825 & 0,9000 & 0 & 4,1905 & 0,0000 & 0 \\
\hline 2000Q3 & 0,0000 & 0,0000 & 0 & 6,1404 & 0,6667 & 0 & 12,6151 & 1,0000 & 1 & 1,0714 & 0,0000 & 0 & $\mathbf{8 , 8 8 2 5}$ & 0,9000 & 1 & 5,5331 & 0,3571 & 0 \\
\hline 2000Q4 & 1,5000 & 0,0000 & 0 & 12,4561 & 0,8333 & 0 & 8,5556 & 0,6364 & 0 & 3,7500 & 0,2000 & 0 & 11,5492 & 0,8571 & 0 & 5,5331 & 0,3571 & 0 \\
\hline 2001Q1 & 1,5000 & 0,0000 & 0 & 12,4561 & 0,8333 & 0 & 8,9484 & 0,6364 & 1 & 3,5204 & 0,2000 & 0 & 10,4063 & $\mathbf{0 , 8 5 7 1}$ & 1 & 5,5331 & 0,3571 & 0 \\
\hline 2001Q2 & 0,0000 & 0,0000 & 0 & 4,7368 & 0,6000 & 1 & 7,1151 & 0,6364 & 1 & 4,2857 & 0,2000 & 0 & 10,0254 & 0,8571 & 0 & 5,5331 & 0,3571 & 1 \\
\hline 2001Q3 & 0,0000 & 0,0000 & 0 & 10,8772 & 1,0000 & 1 & 5,8056 & 0,6250 & 0 & 2,4490 & 0,0000 & 0 & 8,8825 & 0,9000 & 0 & 4,1905 & 0,0000 & 0 \\
\hline 2001Q4 & 1,5000 & 0,0000 & 0 & 10,8772 & 1,0000 & 0 & 4,4306 & 0,6250 & 1 & 5,1276 & 0,3333 & 0 & 10,0254 & 0,8571 & 0 & 12,9177 & 0,6667 & 0 \\
\hline 2002Q1 & 2,5714 & 0,4286 & 0 & 12,4561 & 0,8333 & 1 & 7,1151 & 0,6364 & 0 & 3,5204 & 0,2000 & 0 & 8,2476 & 0,9000 & 1 & 5,5331 & 0,3571 & 0 \\
\hline 2002Q2 & 2,1429 & 0,4286 & 0 & 9,4737 & 0,6667 & 0 & 5,8056 & 0,6250 & 0 & 1,0714 & 0,0000 & 0 & 1,2952 & 0,0000 & 0 & 4,1905 & 0,0000 & 0 \\
\hline 2002Q3 & 1,0714 & 0,0000 & 0 & 10,8772 & 1,0000 & 0 & 5,8056 & 0,6250 & 0 & 1,0714 & 0,0000 & 0 & 3,4540 & 0,1667 & 0 & 5,5331 & 0,3571 & 0 \\
\hline 2002Q4 & 3,6429 & 0,4286 & 0 & 12,4561 & 0,8333 & 1 & 3,0556 & 0,6250 & 0 & 3,7500 & 0,2000 & 0 & 4,5968 & 0,1667 & 0 & 5,5331 & 0,3571 & 0 \\
\hline 2003Q1 & 3,6429 & 0,4286 & 0 & 12,4561 & 0,8333 & 0 & 7,6389 & 0,6364 & 0 & 5,3571 & 0,3333 & 0 & 2,8190 & 0,1667 & 0 & 5,5331 & 0,3571 & 0 \\
\hline 2003Q2 & 2,1429 & $x$ & 0 & 12,4561 & $x$ & 0 & 5,8056 & $\mathrm{x}$ & 0 & 1,0714 & $\mathrm{x}$ & 0 & 2,4381 & $x$ & 0 & 4,1905 & $\mathrm{X}$ & 0 \\
\hline 2003Q3 & 2,1429 & $\mathrm{x}$ & 1 & 12,4561 & $\mathrm{X}$ & 0 & 5,8056 & $\mathrm{X}$ & 0 & 1,0714 & $\mathrm{x}$ & 1 & 4,5968 & $\mathrm{X}$ & 0 & 5,5331 & $\mathrm{X}$ & 0 \\
\hline 2003Q4 & 3,6429 & $\mathrm{x}$ & 0 & 12,4561 & $\mathrm{X}$ & 0 & 5,8056 & $\mathrm{X}$ & 0 & 1,0714 & $\mathrm{X}$ & 0 & 4,5968 & $\mathrm{X}$ & 0 & 5,5331 & $\mathrm{X}$ & 0 \\
\hline
\end{tabular}

Source : Authors' Calculations 

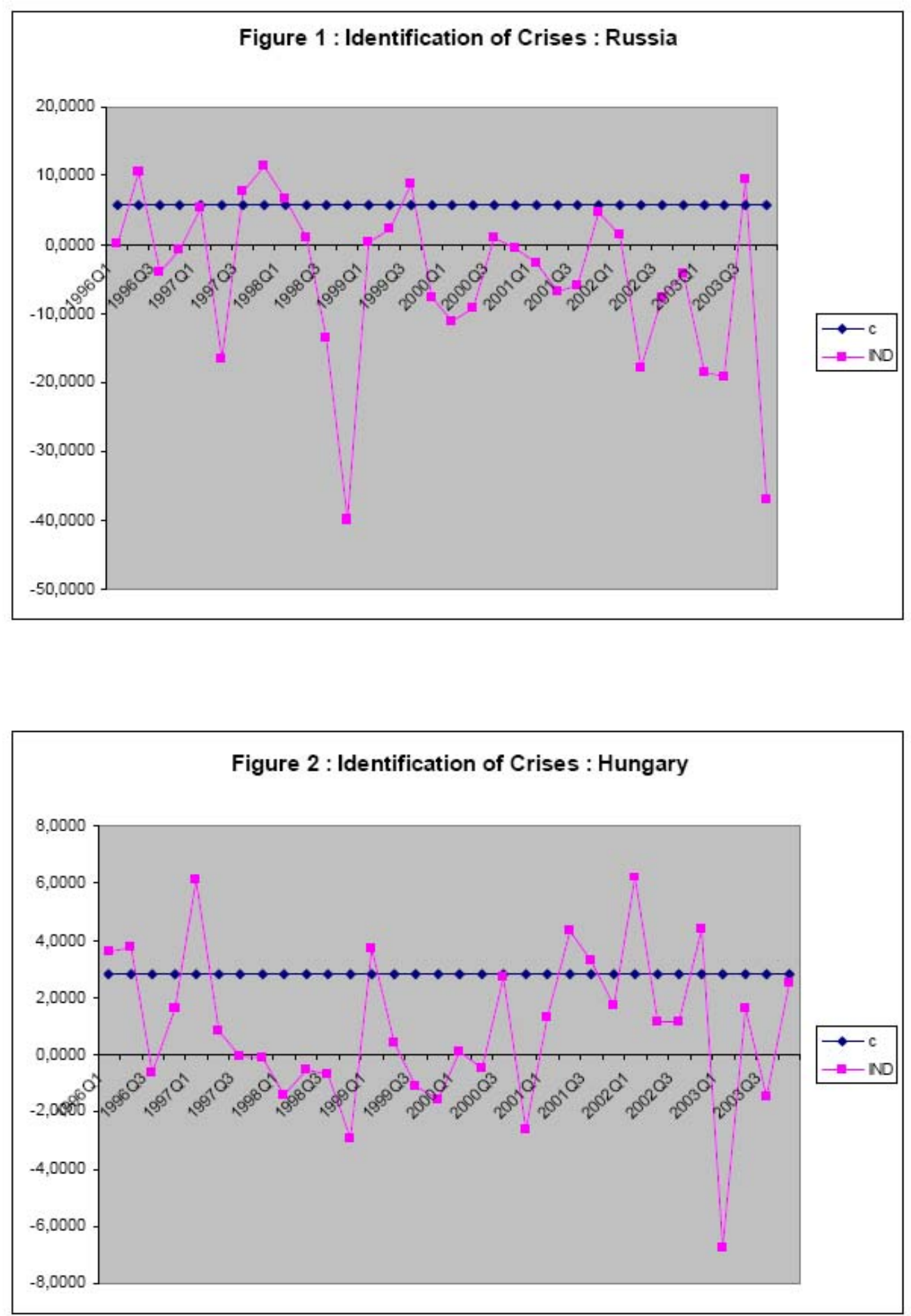

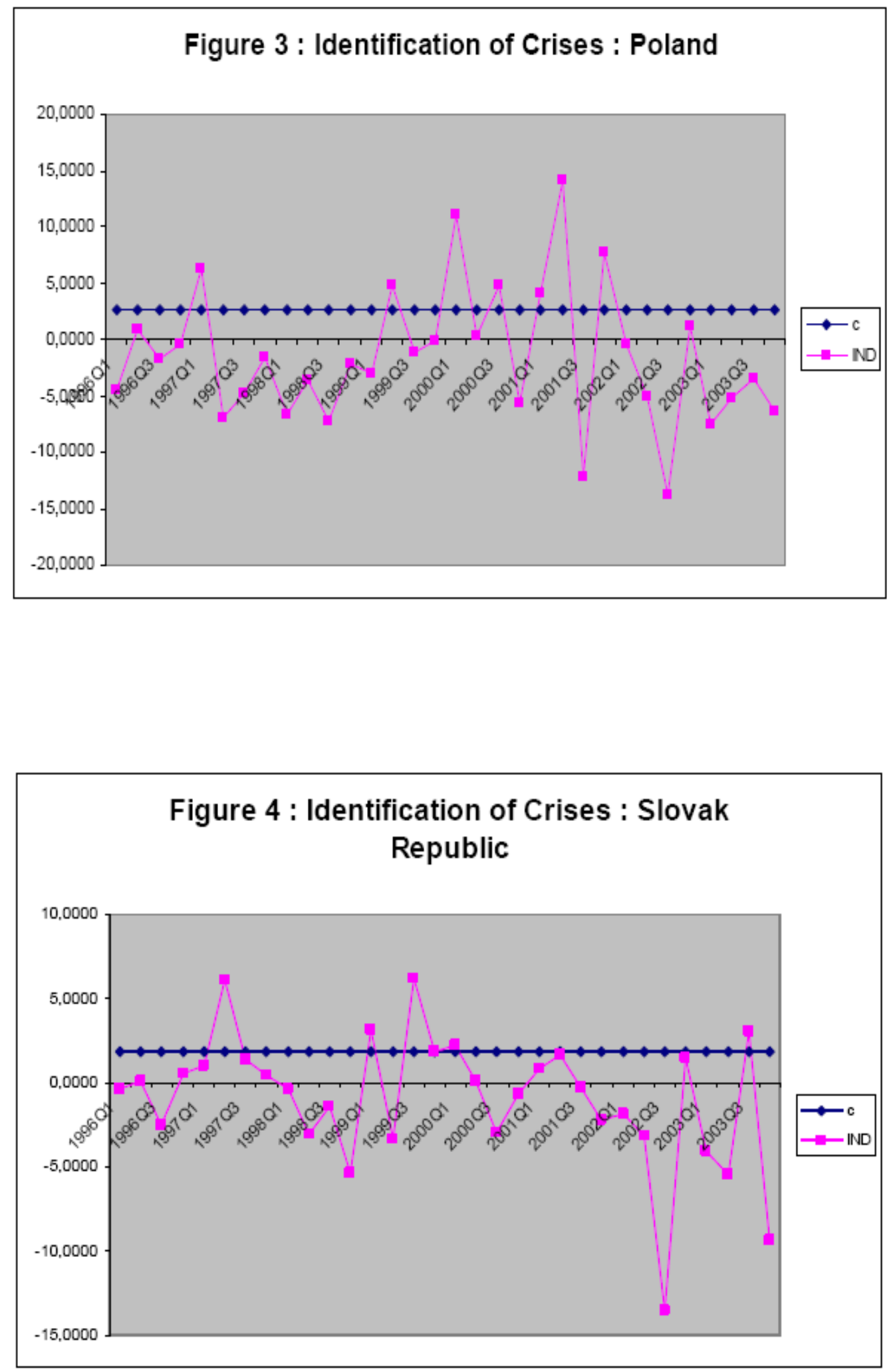
Figure 5 : Identification of Crises : Czech Republic
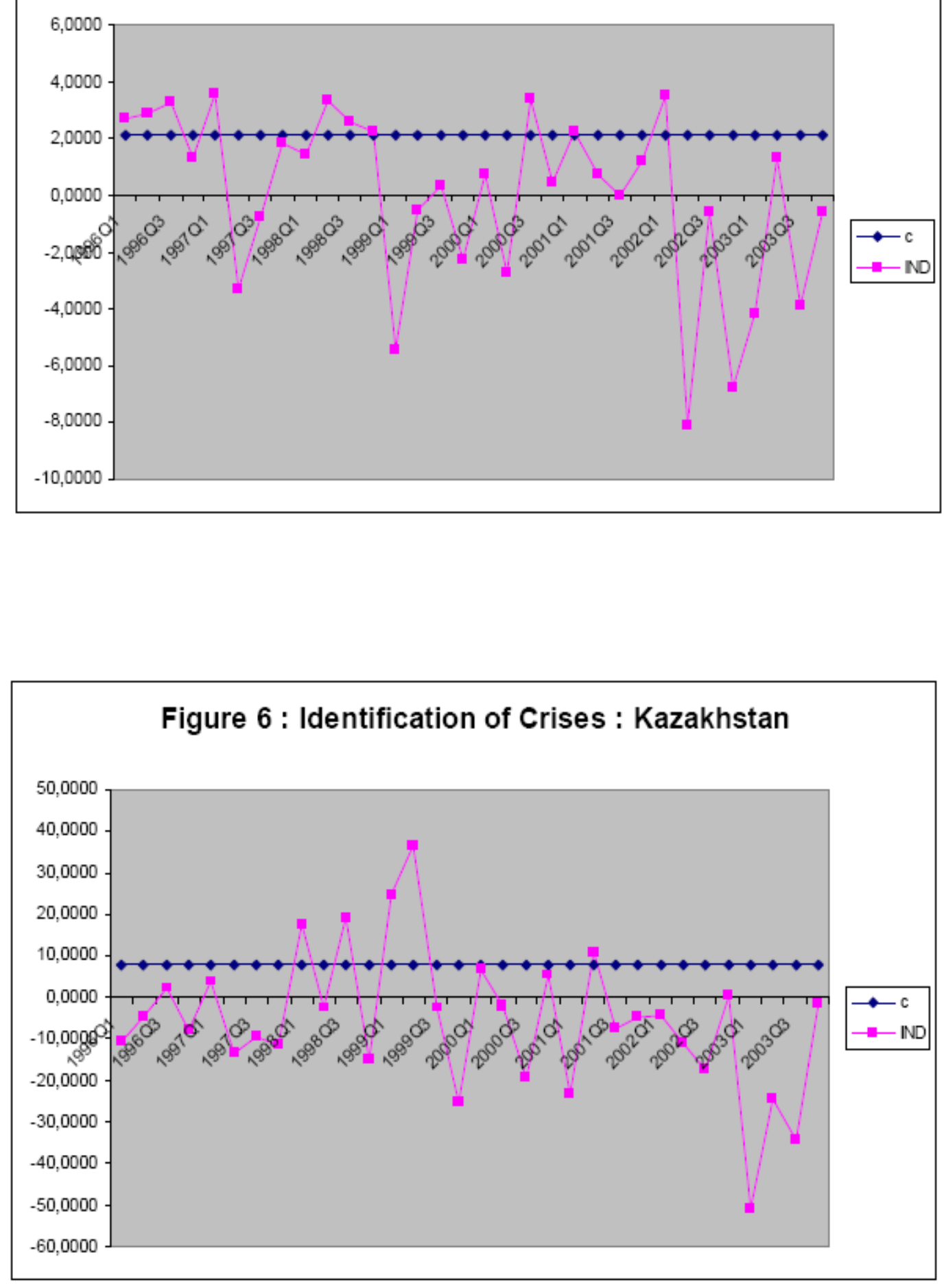


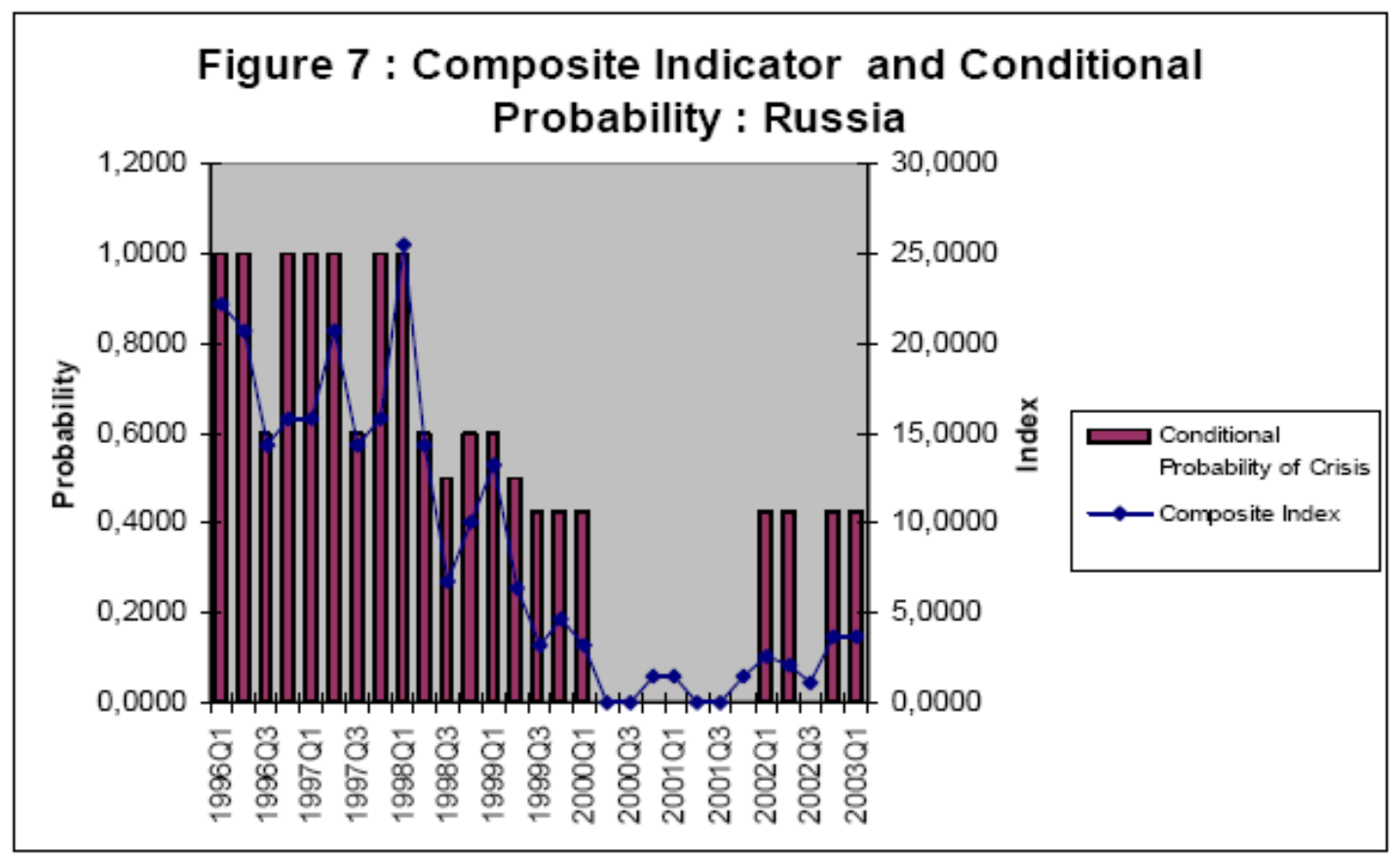

Figure 8 : Composite Indicator and Conditional Probability : Hungary

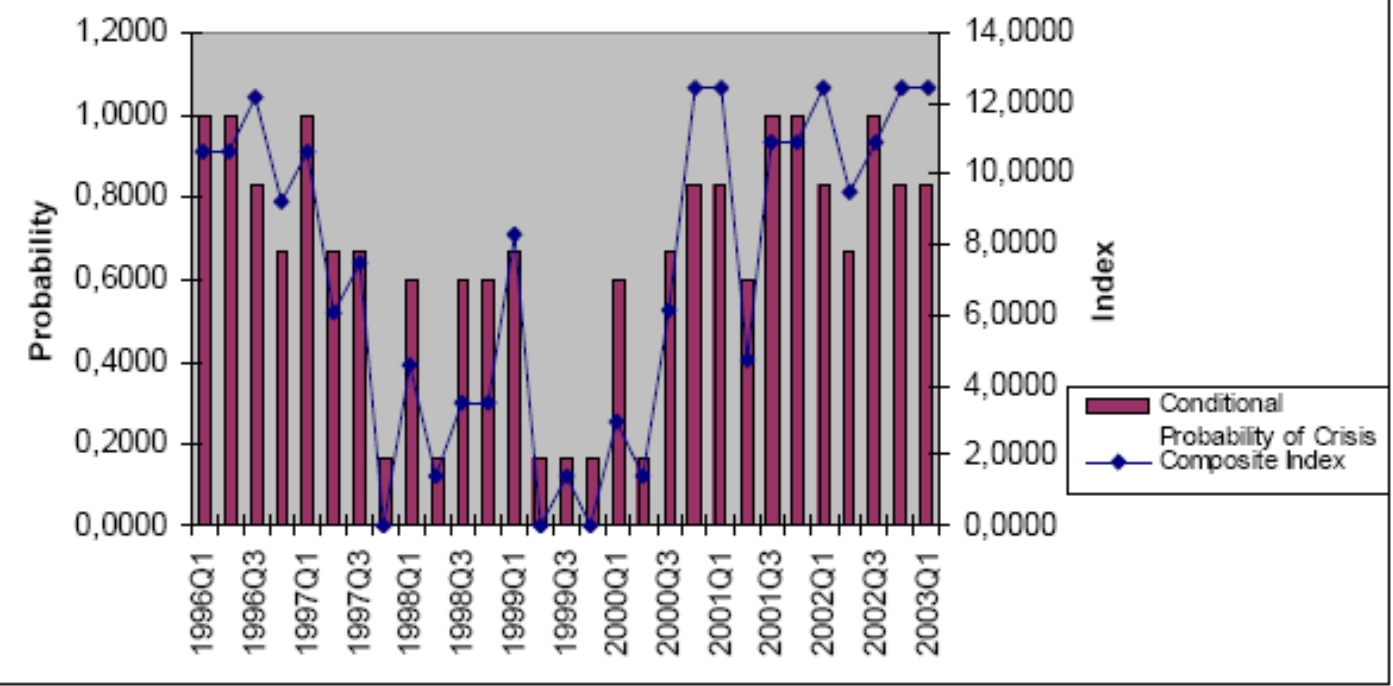


Figure 9 : Composite Indicator and Conditional Probability : Poland

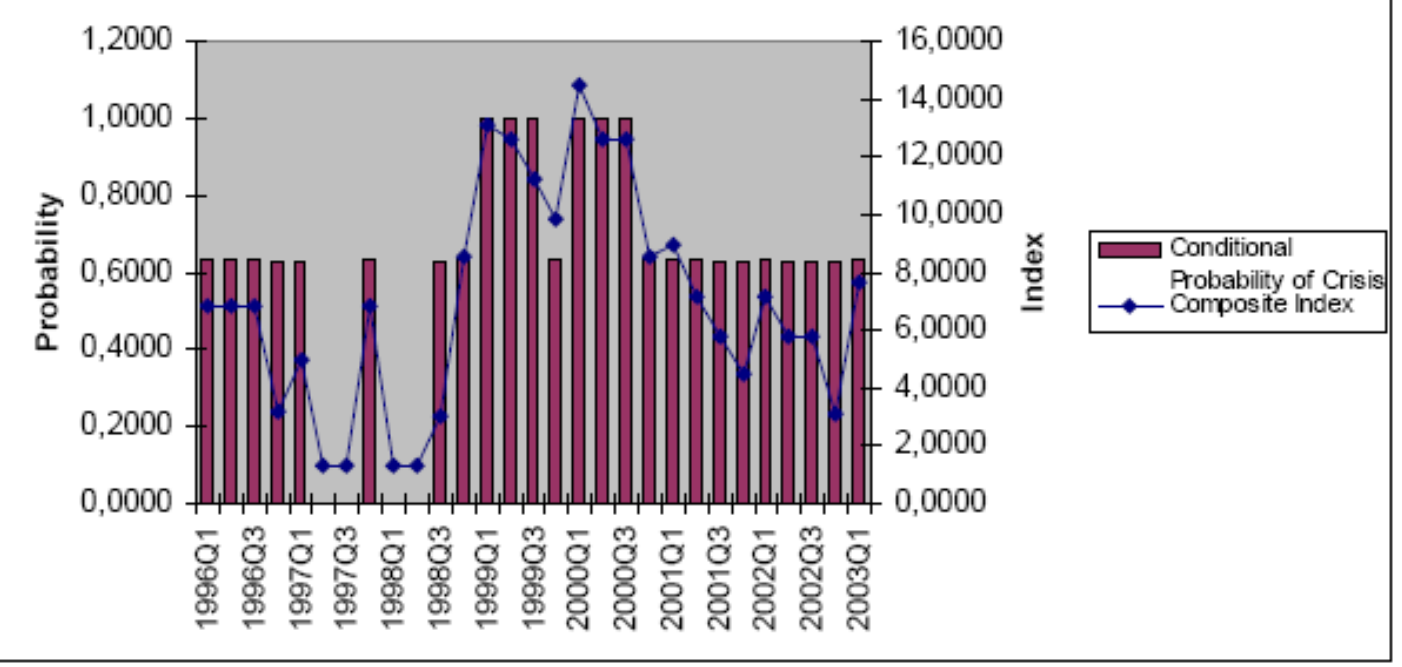

Figure 10 : Composite Indicator and Conditional Probability : Slovak Republic

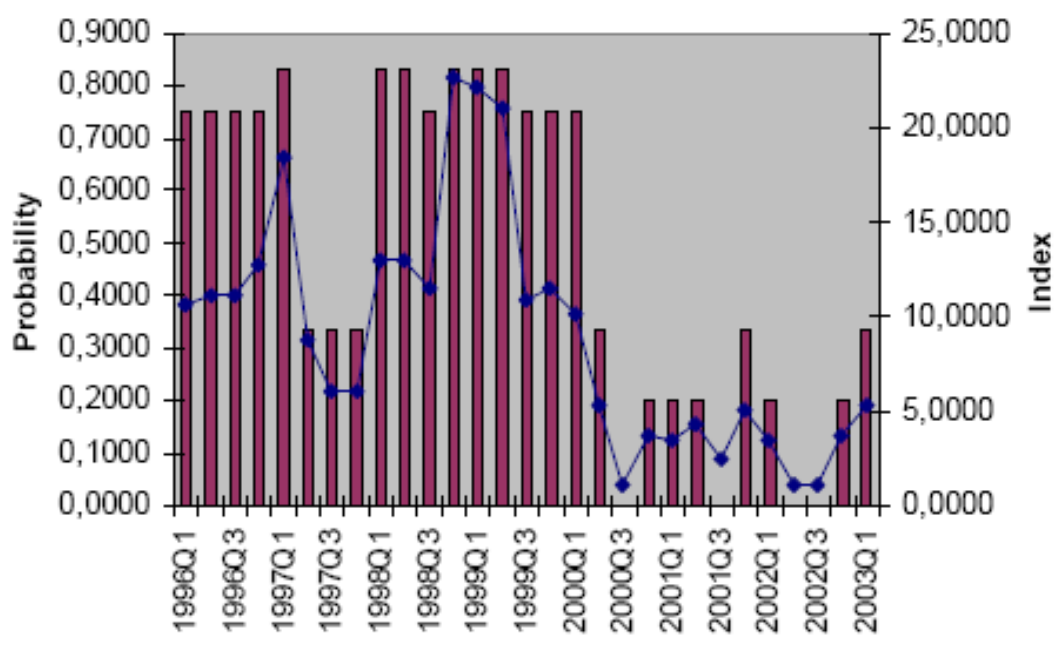



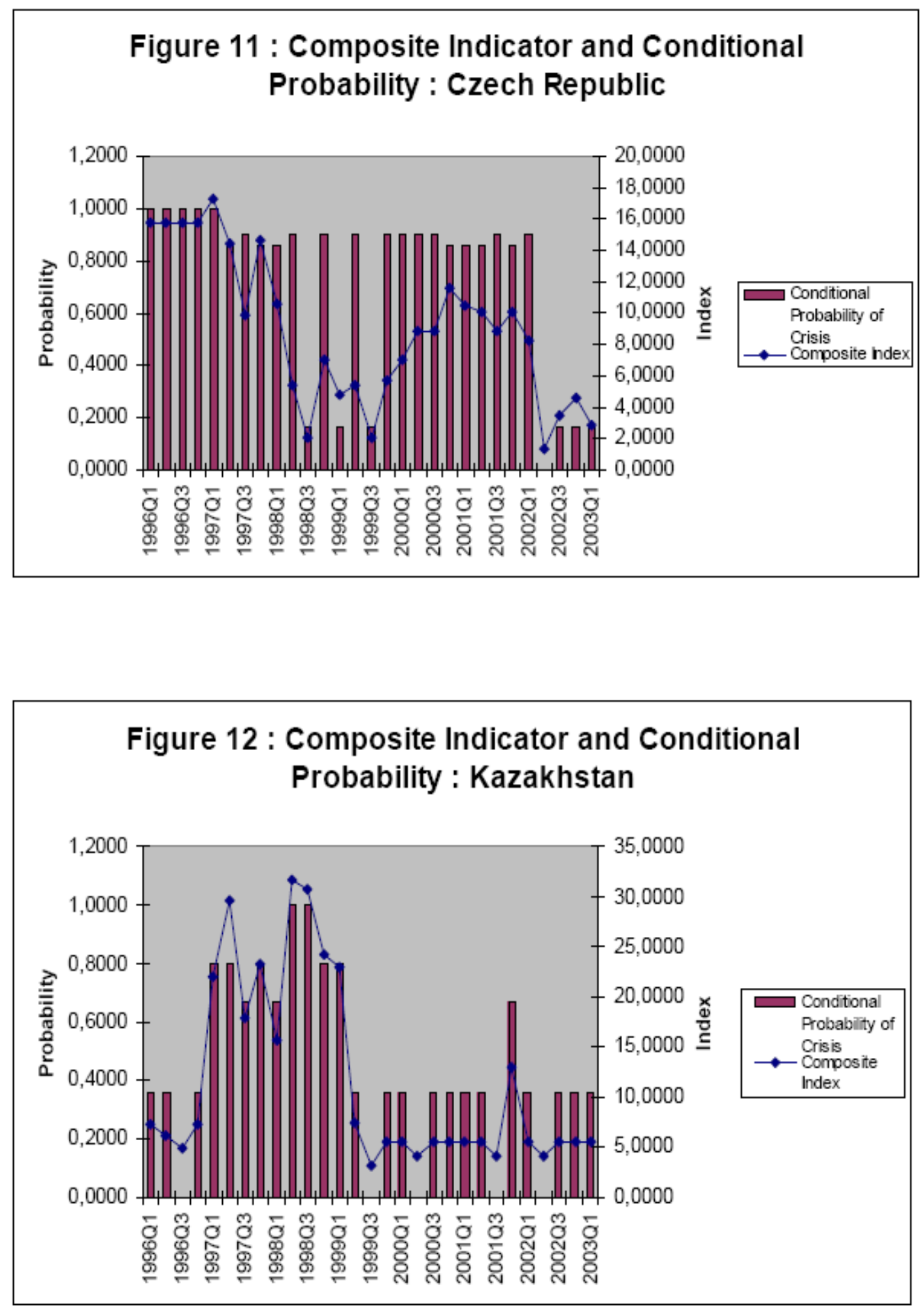


\section{References}

[1] Abiad, A., 2003, Early-warning systems: a survey and a regime-switching approach, IMF Working Paper 03/32.

[2] Arias, G. and U.G. Erlandsson, 2004, Regime switching as an alternative early warning system of currency crises. An application to South-East Asia, Working Paper, Lund University, Sweden.

[3] Berg, A. and C. Patillo, 1999, Are currency crises predictable? A test, IMF Staff Papers 46(2), 107-138.

[4] Bubula, A., Otker-Robe, I., 2003, Are pegged and intermediate exchange rate regimes more crisis prone?, IMF Working Paper 03/223.

[5] Burkart, O. and V. Coudert, 2002, Leading indicators of currency crises for emerging economies, Emerging Market Review 3, 107-133.

[6] Bussière, M. and M. Fratzscher, 2002, Towards a new early warning system of financial crises, Working Paper, European Central Bank.

[7] Darvas Z., Szapary G., 2000, Financial Contagion in five small open economies : does the exchange rate regime really matter?, International Finance, Vol. 3, 25-51.

[8] Edison, H.J., 2003, Do indicators of financial crises work? An evaluation of an early warning system, International Journal of Finance and Economics 8(1), 11-53.

[9] Eichengreen, B., Rose, A. and Wyplosz, 1996, Contagious currency crises, NBER Working Paper N[EQUATION] 5681, Cambridge, National Bureau of Economic Research.

[10] Flood, R.P. and P. Garber, 1984, Collapsing Exchange Rates: some linear examples, Journal of International Economics 17, 1-13.

[11] Glick, R. and A. Rose, 1999, Contagion and trade: why are currency crises regional?, Journal of International Money and Finance 18(4), 603-618.

[12] Goldstein, M., Kaminsky, G.L. and C. Reinhart, 2000, Assessing Financial Vulnerability. An early warning system for emerging markets, Institute for International Economics, Washington.

[13] Kaminsky, G., Lizondo, S., Reinhart, C., 1998, Leading Indicators of Currency Crises, IMF Staff Papers, Vol. 45 (march), 1-48.

[14] Kaminsky, G. and C.M. Reinhart, 2000, On crises, contagion and confusion, Journal of International Economics 51, 145-168.

[15] Komulainen,T. and J. Lukkanila, 2002, What drives financial crises in emerging markets?, Emerging Markets Review, 4(3), 248-272. 
[16] Krugman, P., 1979, A model of balance of payments crises, Journal of Money Credit and Banking 11, 311-325.

[17] Krugman, P., 1998, What happened to Asia, MIT, Mimeo.

[18] Kumar, M., Moorthy, U. and W. Perraudin, 2003, Predicting emerging market crashes, Journal of Empirical Finance 10(4), 427-454.

[19] Sachs, J.D., Tornell, A. and A. Velasco, 1996, Financial crises in emerging markets: the lessons from 1995, Brookings Papers on Economics Activities, 147-198.

[20] Schweickert R., Vinhas de Souza L., 2005, Vulnerability to crisis under different exchange rate regimes : an early warning system for Russia and Brazil, Draft, Kiel Institute for World Economics, European Commission. 


\section{DAVIDSON INSTITUTE WORKING PAPER SERIES - Most Recent Papers}

The entire Working Paper Series may be downloaded free of charge at: www.wdi.umich.edu

CURRENT AS OF 11/19/07

\begin{tabular}{|c|c|c|}
\hline Publication & Authors & Date \\
\hline $\begin{array}{l}\text { No. 901: A Forewarning Indicator System For Financial Crises : The } \\
\text { Case Of Six Central And Eastern European Countries }\end{array}$ & $\begin{array}{l}\text { Irène Andreou, Gilles Dufrénot, } \\
\text { Alain Sand-Zantman, and } \\
\text { Aleksandra Zdzienicka-Durand }\end{array}$ & May 2007 \\
\hline No. 900: Directional Mobility of Debt Ratings & $\begin{array}{l}\text { Sumon Kumar Bhaumik and John } \\
\text { S. Landon-Lane }\end{array}$ & Nov 2007 \\
\hline $\begin{array}{l}\text { No. 899: The Choice of Exchange Rate Regimes in the MENA Countries: } \\
\text { a Probit Analysis }\end{array}$ & Sfia M. Daly & Oct 2007 \\
\hline $\begin{array}{l}\text { No. 898: Macroeconomic Sources of Foreign Exchange Risk } \\
\text { in New EU Members }\end{array}$ & $\begin{array}{l}\text { Evzen Kocenda and Tirgran } \\
\text { Poghosyan }\end{array}$ & Oct 2007 \\
\hline $\begin{array}{l}\text { No. 897: Rapid Economic Growth And Industrialization } \\
\text { In India, China \& Brazil: At What Cost? }\end{array}$ & Krishna Chaitanya.V & Oct 2007 \\
\hline $\begin{array}{l}\text { No. 896: Factors influencing corporate governance in post-socialist } \\
\text { companies: an analytical framework }\end{array}$ & $\begin{array}{l}\text { Andreas Heinrich, Aleksandra Lis } \\
\text { and Heiko Pleines }\end{array}$ & Oct 2007 \\
\hline $\begin{array}{l}\text { No. 895: Real Convergence, Price Level Convergence and Inflation } \\
\text { Differentials in Europe }\end{array}$ & Balázs Égert & Oct 2007 \\
\hline No. 894: Determinants of House Prices in Central and Eastern Europe & $\begin{array}{l}\text { Balázs Égert and Dubravko } \\
\text { Mihaljek }\end{array}$ & Oct 2007 \\
\hline $\begin{array}{l}\text { No. 893: What Do We Really Know About Fiscal Sustainability in the } \\
\text { EU? A Panel Data Diagnostic }\end{array}$ & $\begin{array}{l}\text { António Afonso and Christophe } \\
\text { Rault }\end{array}$ & Oct 2007 \\
\hline $\begin{array}{l}\text { No. 892: The Political Economy of Corruption and the Role of Financial } \\
\text { Institutions }\end{array}$ & Kira Boerner and Christa Hainz & Oct 2007 \\
\hline $\begin{array}{l}\text { No. 891: Growth, Volatility and Political Instability: Non-Linear time } \\
\text { Series Evidence for Argentina 1896-2000 }\end{array}$ & $\begin{array}{l}\text { Nauro Campos and Menelaos } \\
\text { Karanasos }\end{array}$ & Sept 2007 \\
\hline No. 890: Social Costs of Mass Privatization & $\begin{array}{l}\text { David Stuckler and Lawrence } \\
\text { King }\end{array}$ & Sept 2007 \\
\hline $\begin{array}{l}\text { No. 889: A Rise By Any Other Name? Sensitivity of Growth Regressions } \\
\text { to Data Source }\end{array}$ & $\begin{array}{l}\text { Randall Filer, Dana Hajkova and } \\
\text { Jan Hanousek }\end{array}$ & July 2007 \\
\hline No. 888: Mind the Gap! Social Capital, East and West & Jan Fidrmuc and Klarita Gerxhani & June 2007 \\
\hline No. 887: Ever Closer Union or Babylon Discord? & $\begin{array}{l}\text { Jan Fidrmuc, Victor Ginsburgh } \\
\text { and Schlomo Weber }\end{array}$ & July 2007 \\
\hline $\begin{array}{l}\text { No. 886: FDI \& the Consequences towards more complete capture of } \\
\text { spillover effects }\end{array}$ & $\begin{array}{l}\text { Bruno Merlevede and Koen } \\
\text { Schoors }\end{array}$ & Aug 2007 \\
\hline No. 885: Consumption Smoothing and Vulnerability in Russia & $\begin{array}{l}\text { Christopher J. Gerry and Carmen } \\
\text { A. Li }\end{array}$ & July 2007 \\
\hline No. 884: National Cultural \& Financial Systems & $\begin{array}{l}\text { Solomon Tadesse and Chuck } \\
\text { Kwok }\end{array}$ & $\begin{array}{l}\text { March } \\
2005\end{array}$ \\
\hline $\begin{array}{l}\text { No. 883: Stock Markets Liquidity, Corporate Governance and Small } \\
\text { Firms }\end{array}$ & Solomon Tadesse & June 2005 \\
\hline $\begin{array}{l}\text { No. 882: The MNC as an Agent of Change for Host-Country Institutions: } \\
\text { FDI \& Corruption }\end{array}$ & $\begin{array}{l}\text { Chuck Kwok and Solomon } \\
\text { Tadesse }\end{array}$ & Sept 2006 \\
\hline $\begin{array}{l}\text { No. 881: The Allocation and Monitoring Role of Capital Markets: } \\
\text { Theory and International Evidence }\end{array}$ & Solomon Tadesse & $\begin{array}{l}\text { March } \\
2003\end{array}$ \\
\hline No. 880: Tunisia: Sources of Real Exchange Rate Fluctuations & Sfia Mohamed Daly & $\begin{array}{l}\text { March } \\
2006\end{array}$ \\
\hline No. 879: Financial Development \& Technology & Solomon Tadesse & June 2007 \\
\hline $\begin{array}{l}\text { No. 878: Consolidation, Scale Economics \& Technological Change in } \\
\text { Japanese Banking }\end{array}$ & Solomon Tadesse & Feb 2005 \\
\hline No. 877: Innovation, Information and Financial Architecture & Solomon Tadesse & June 2007 \\
\hline $\begin{array}{l}\text { No. 876: Corporate Cash Holdings, National Culture, and } \\
\text { Multinationality }\end{array}$ & $\begin{array}{l}\text { Andres Ramirez and Solomon } \\
\text { Tadesse }\end{array}$ & June 2007 \\
\hline
\end{tabular}

